\title{
Physical and Mechanical Properties of High Alumina Refractory Materials for shielding Applications of Steam Reformer Reactor
}

\author{
Waleed.A.Mohrez \\ The Nuclear Materials Authority of Egypt \\ Post box No 530 Maadi Egypt
}

\begin{abstract}
This research studied the physical properties of high alumina refractory materials, which are using as lining material in the primary and secondary reformer for Ammonia production in Kima project of Aswan City, Egypt .The study focused on the effect of materials balance variations of the mixture content, with different chemical recipes on The physical and mechanical properties which are affected by the in-service conditions of the primary and secondary reformer; these physical and mechanical properties are ; the bulk density, the thermal conductivity, permanent linear change (PLC), the cold crushing strength.
\end{abstract}

Key Words: Primary and secondary Reformer, alumina base refractory materials, ASTM C134,C133, C856, Ammonia production process.

DOI: $10.7176 / \mathrm{CMR} / 11-7-05$

Publication date:September 30th 2019

\section{Introduction}

Steam reforming of natural gas is the most common method of producing commercial bulk hydrogen at about $95 \%$ of the world production [1, 2] of 500 billion $\mathrm{m}^{3}$ in 1998. [3] Hydrogen is used in the industrial synthesis of ammonia and other chemicals.[4] At high temperatures $\left(700-1100^{\circ} \mathrm{C}\right)$ and in the presence of a metalbased catalyst (nickel), steam reacts with methane to yield carbon monoxide and hydrogen ,according to the reaction; $\mathrm{CH}_{4}+\mathrm{H}_{2} \mathrm{O} \rightleftharpoons \mathrm{CO}+3 \mathrm{H}_{2}$.

Due to high temperature it is indispensable to use high durable refractory materials to resist and insulate such high temperature and keep the heat balance required to achieve the reaction. The refractory tiles supposed to be mounted in internal wall of the reformer as illustrated in the attached schematic design, Fig.1 [5]

In this research i used high alumina refractory material, with a different chemical recipes of alumina, silica, iron oxide and titanium dioxide, $\mathrm{CaO}$, Magnesia, Alkalis $(\mathrm{Na} 2 \mathrm{O}+\mathrm{K} 2 \mathrm{o})$,phosphorous Pentoxide [6] the mixing and dry out of this mixtures was done in accordance to the technology provider of Reformer technology KBR[6]

The main criteria used to test the produced refractory product is; the bulk density, permanent linear change (PLC), the cold crushing strength. [7,8]

All the activity of the research has been accomplished at the site of the Urea and Ammonia project under construction at ASWAN city in the south of Egypt under the authority of the company of Orascom construction. 


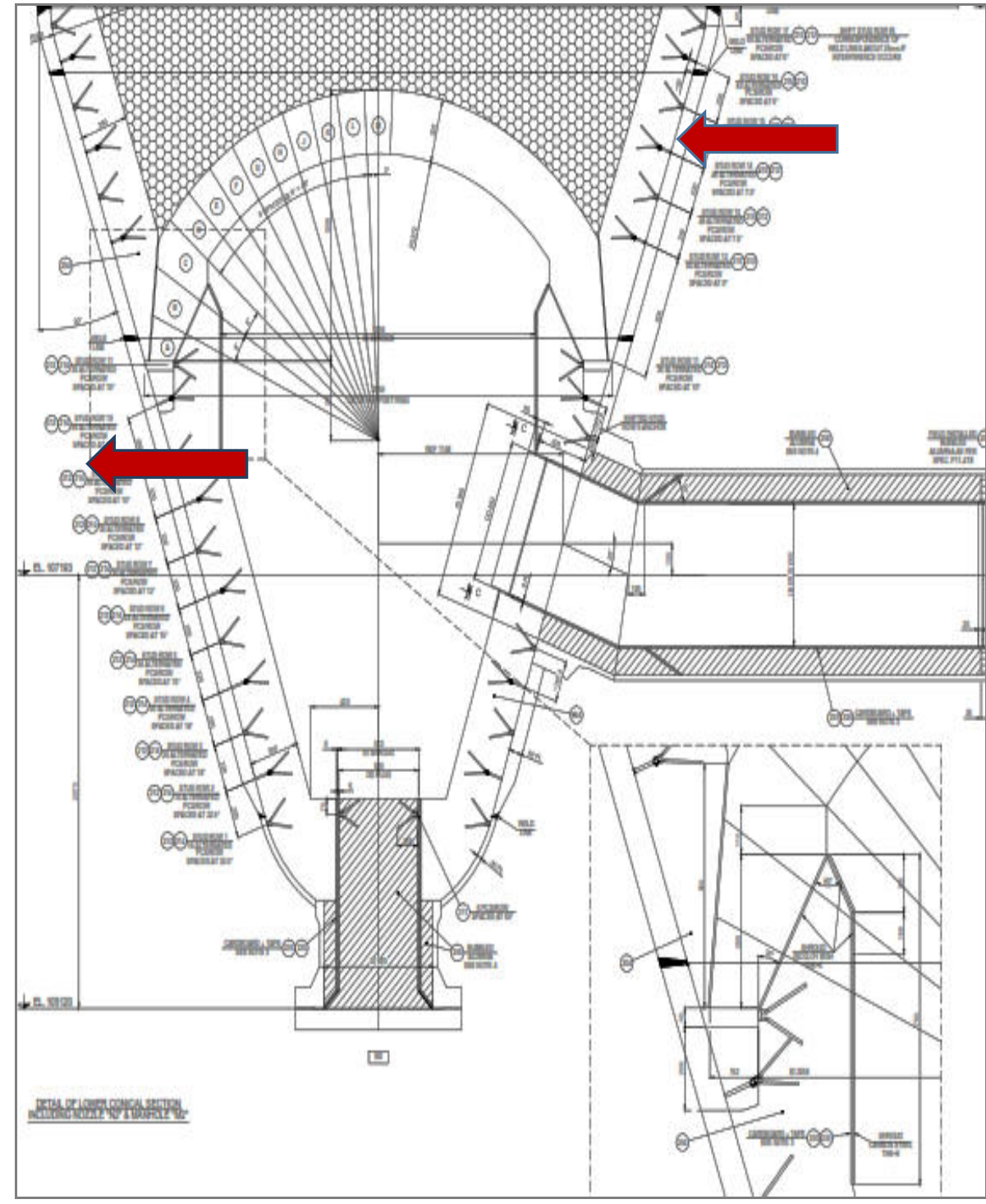

Fig.1. Schematic view of the internal side wall of the reformer illustrating the location of the refractory tile in the direction of the red arrow

\section{Experimental Work}

The experimental work started with materials preparation with a different recipes, where I selected the alumina from manufacturer with brand name called Al100 and the white sand as source of silica, hematite as source of iron oxide, Anatase form of $\mathrm{TiO}_{2}$ white pigment, and calcium carbonate as source of $\mathrm{CaO}$, Dolomite as source of Magnesia, Sodium hydroxide as source of $\mathrm{Na}_{2} \mathrm{O}$, potassium hydroxide as source of $\mathrm{K} 2 \mathrm{O}$, and Apatite as source of the phosphorous pentoxide. The mineral balance weigh will be kept as knowhow and knowledge preservation but the analysis of the balance of the all oxide will be demonstrated to show the variation recipes. The recipes are as follow in table 1, were it has been categorized into four categories; A, B, C, D where category \#A has only content of $\mathrm{Al}_{2} \mathrm{O}_{3}, \mathrm{SiO}_{2}, \mathrm{Fe}_{2} \mathrm{O}_{3}$ and the percentage of Alumina was changed, in Category \#B I added content of Calcium oxide and Magnesia, Alkalis, and the content of both alumina and Calcium oxide were changed, in Category \#C I added $\mathrm{TiO} 2$ and phosphorous pentoxide, where percentage of $\mathrm{Al} 2 \mathrm{O} 3, \mathrm{SiO} 2, \mathrm{P} 2 \mathrm{O} 5$ were changed, in category \# D I discarded the content of $\mathrm{P} 2 \mathrm{O} 5$ and changed the percentage of both $\mathrm{Al} 2 \mathrm{O} 3$ and $\mathrm{CaO}$ 
Table.1: The recipes percentage content by weight

\begin{tabular}{|c|c|c|c|c|c|c|c|c|c|}
\hline $\begin{array}{c}\text { Recipes } \\
\text { Categories }\end{array}$ & $\begin{array}{c}\text { Recipe No } \\
\text { /Sample ID }\end{array}$ & $\begin{array}{c}\mathrm{Al}_{2} \mathrm{O}_{3} \\
\% \\
\%\end{array}$ & $\begin{array}{c}\mathrm{SiO}_{2} \\
\\
\% \\
\end{array}$ & $\begin{array}{c}\mathrm{Fe}_{2} \mathrm{O}_{3} \\
\\
\% \\
\end{array}$ & $\begin{array}{c}\mathrm{TiO}_{2} \\
\\
\% \\
\end{array}$ & $\begin{array}{c}\mathrm{CaO} \\
\% \\
\%\end{array}$ & $\begin{array}{c}\text { MgO } \\
\% \\
\%\end{array}$ & $\begin{array}{c}\text { Alkalis } \\
\mathrm{Na}_{2} \mathrm{O}, \mathrm{K}_{2} \mathrm{O} \\
\% \\
\%\end{array}$ & $\begin{array}{c}\mathrm{P}_{2} \mathrm{O}_{5} \\
\% \\
\%\end{array}$ \\
\hline \multirow[t]{3}{*}{ A } & Al01 & 99.5 & 0.1 & 0.1 & & & & & \\
\hline & Al02 & 95 & 0.2 & 0.2 & & & & & \\
\hline & Al03 & 90 & 0.4 & 0.4 & & & & & \\
\hline \multirow[t]{3}{*}{ B } & Al04 & 94.3 & 0.1 & 0.1 & & 5 & 0.1 & 0.4 & \\
\hline & Al05 & 93.3 & 0.1 & 0.1 & & 6 & 0.1 & 0.7 & \\
\hline & Al06 & 92.3 & 0.1 & 0.1 & & 7 & 0.1 & 0.7 & \\
\hline \multirow[t]{3}{*}{ C } & Al07 & 91 & 5 & 0.1 & 0.1 & 0.1 & 0.2 & 0.3 & 3.2 \\
\hline & Al08 & 88 & 6 & 0.1 & 0.1 & 0.1 & 0.2 & 0.3 & 5.2 \\
\hline & Al09 & 85 & 7 & 0.1 & 0.1 & 0.1 & 0.2 & 0.3 & 7.2 \\
\hline \multirow[t]{3}{*}{ D } & Al10 & 94.5 & 0.5 & 0.1 & 0.1 & 4.4 & 0.1 & 0.4 & \\
\hline & Al11 & 90.5 & 0.5 & 0.1 & 0.1 & 8.4 & 0.1 & 0.4 & \\
\hline & Al12 & 85.5 & 0.5 & 0.1 & 0.1 & 13.4 & 0.1 & 0.4 & \\
\hline
\end{tabular}

\subsection{Materials preparation}

All minerals had been grinded and sieved to be less than 500 micron and then dried mixed for 10 minutes, to assure from homogeneity before wet mixing by water addition [16-21]

\subsection{Wet mixing}
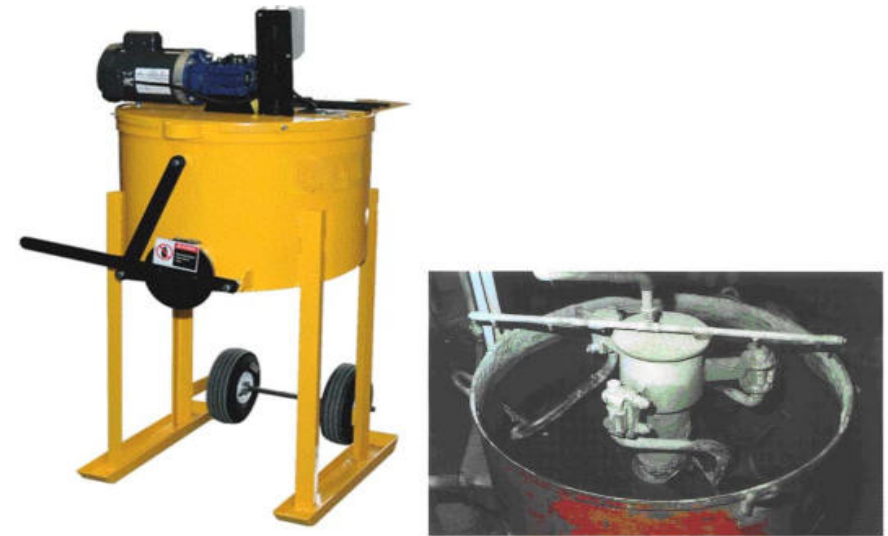

In this step 10 kilograms of each sample ID after dray mixing were poured inside the mechanical vibrator mixer

(Fig.2.) for 10 minutes and then adding the total weight of water which representing $12 \%$ of the total weight of the sample, the pouring of the water shall be done into two half; one half after mixing 10 minutes and the other half shall be after 10 minutes, the wet mixing continue for 20 minutes [16-21]. there are controlling method to test the quality of mixing; called ball in hand test each sample is taken from the mixer and rounding it like a ball if the mixture was loose and not adhered then the mixer needs more water if the ball in hand was sticky and rounded it means that the water content is optimum, if the ball in hand was fluidized then the water is much more than required, Fig.3. Showed the criteria of the ball in hand test $[\mathbf{2 2}, \mathbf{2 3}]$ 

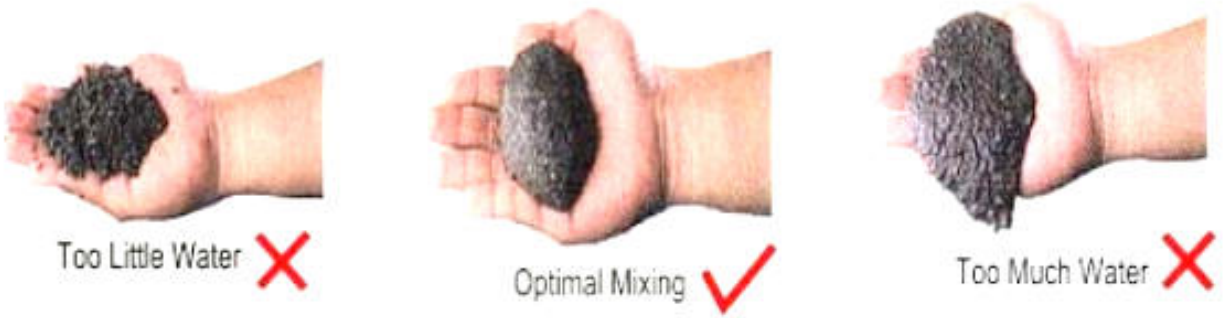

Fig.3.Schematic View of ball in hand test rejection and acceptance criteria

\subsection{Pouring in Cubic Molds}

After adjustment and monitoring of the mixing process by ball in hand test, the mixed recipe of each sample from each category A,B,C,D were poured into wooden cubic molds with a dimensions 50X50X230 mm and dimensions $50 \times 50 \times 50 \mathrm{~mm}$ to use it for the test required after curing and drying. The total number of samples to cover the required tests are 264 specimens.

\subsection{Curing and Dry Out}

At this stage all molded samples shall be dried and cured in accordance to the specifications of KBR design criteria, where it designed to the fitness for services[6].the regime of dry out and curing is to make ignition and heat up to $135^{\circ} \mathrm{C}$ with a rate of $15^{\circ} \mathrm{C} / \mathrm{hr}$, then hold 8 hours in temperature $135^{\circ} \mathrm{C}$, after that heating up to $300^{\circ} \mathrm{C}$ at rate of $15^{\circ} \mathrm{C} / \mathrm{hr}$. then holding temperature for $12 \mathrm{hr}$, then heating up the temperature to $480^{\circ} \mathrm{C}$ at the rate $15^{\circ} \mathrm{C} / \mathrm{hr}$ and directly go forward to heat up the temperature to $950^{\circ} \mathrm{C}$ at rate $50^{\circ} \mathrm{C} / \mathrm{hr}$, then holding the temperature at $950^{\circ} \mathrm{C}$ for $24 \mathrm{hr}$,after that the temperature shall be descended to $200^{\circ} \mathrm{C}$ at rate of $25^{\circ} \mathrm{C} / \mathrm{hr}$. The curing and dry out regime is showed in Fig.4.

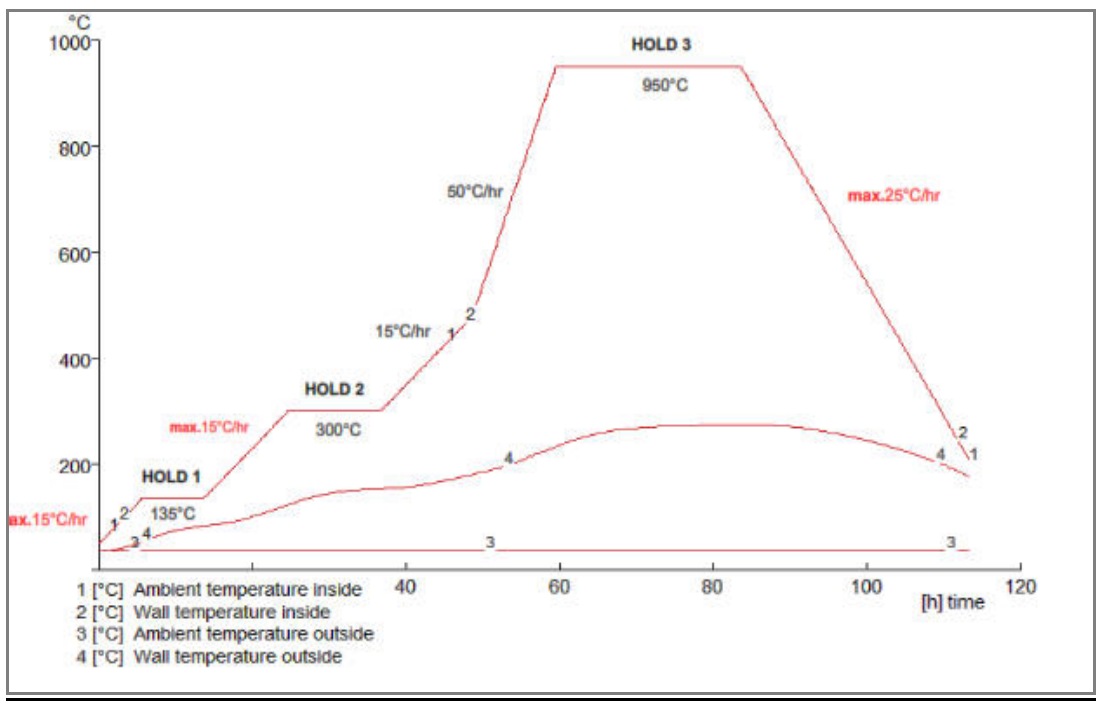

Fig.4.the curing and dry out regime 


\subsection{Sounding Test}

The purpose of this test to sort the samples which have no any defect due to the casting and mixing or any defect regarding to the preparation to judge on the samples in according to variation of its material balance only. This test have been conducted by phased array technique by using apparatus of OMNISX-PA1664PR with 16 piezo electric elements. Test was done for all test samples and selected only the sounded samples and neglect all samples which have defects. The test have been repeated twice to increase the reliability as shown in Fig.5a,b where A scan showed no defect indications and also b scan but in $\mathrm{C}$ scan showed some textures indications regarding to sound noise but when repeated due to different calibration and neglecting the noise effect of the device showed completely sounded indications in Fig.5b.
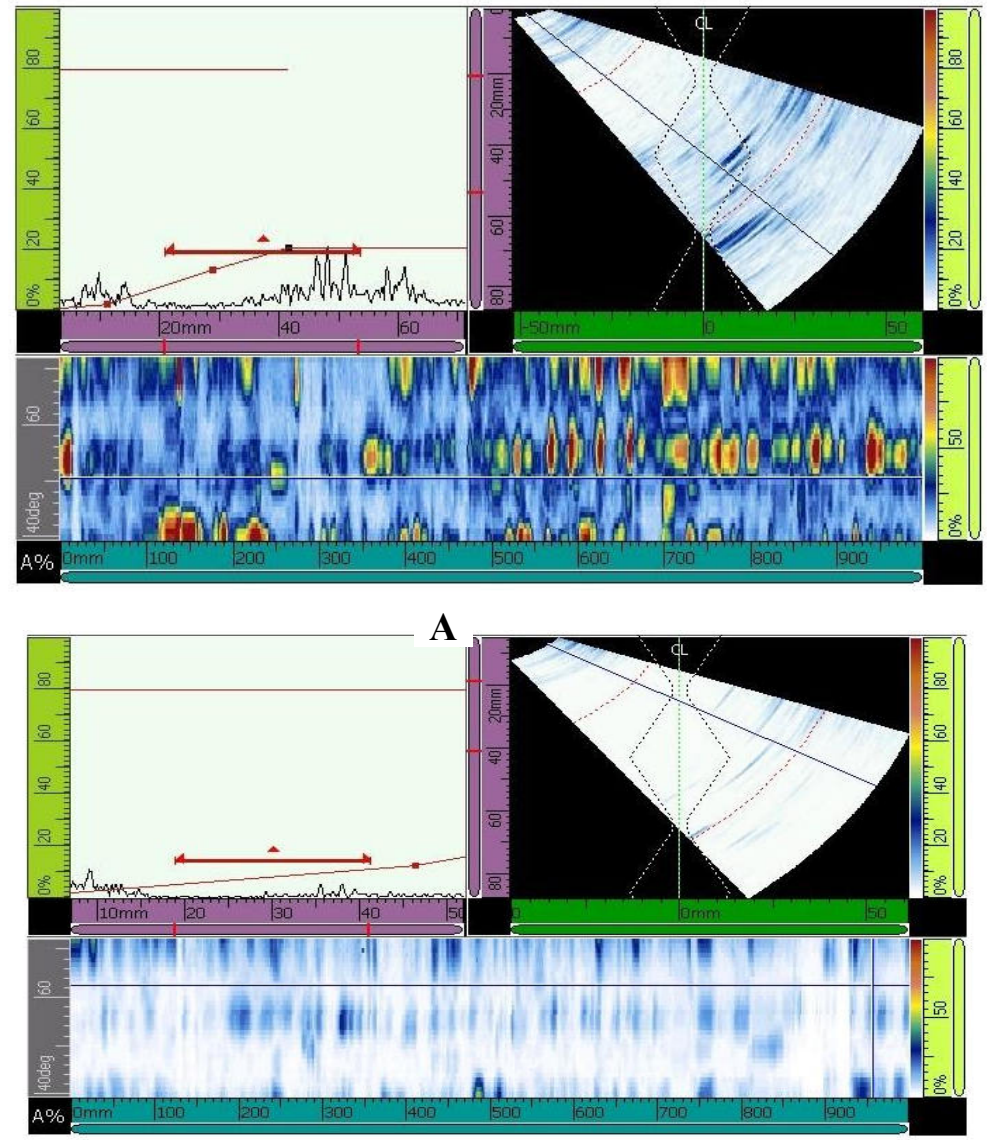

B

Fig.5. Results of tests by Phased Array method showed soundness of test samples

\subsection{Testing Required for Sample Evaluation}

The test specimens of each category were tested and evaluated, where thermal conductivity test has been conducted by the device; DFX200 High speed Xenon-pulse delivery source and solid state PIN detector for unmatched sensitivity down to $-150^{\circ} \mathrm{C}$ as shown in Fig.6.A., Also the bulk density was tested in accordance to ASTM C134 by device of XQK Ceramic refractory products apparent porosity bulk density as shown in Fig.6B., also cold crushing strength was tested in accordance to ASTM C133 by apparatus of PERCISION as shown in figure Fig.6C.., the permanent linear change also was tested in accordance to ASTM C113 by universal testing machine with furnace escalated temperature as shown in Fig.6.D 


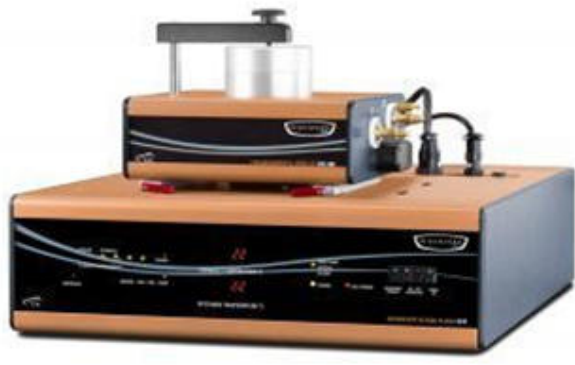

A

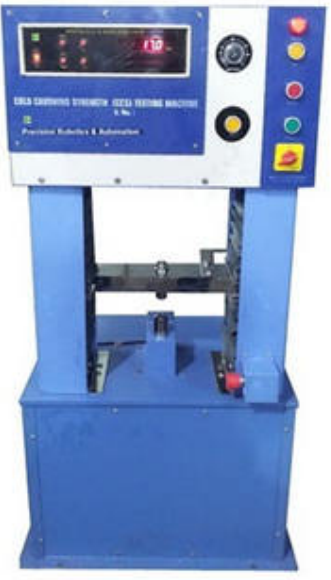

C

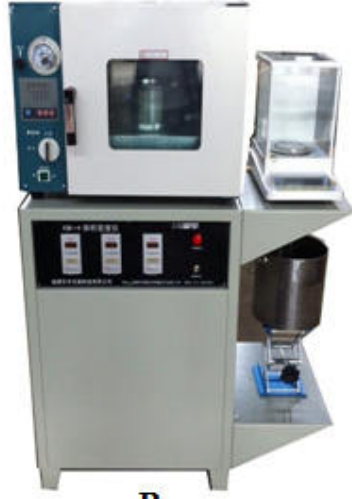

B

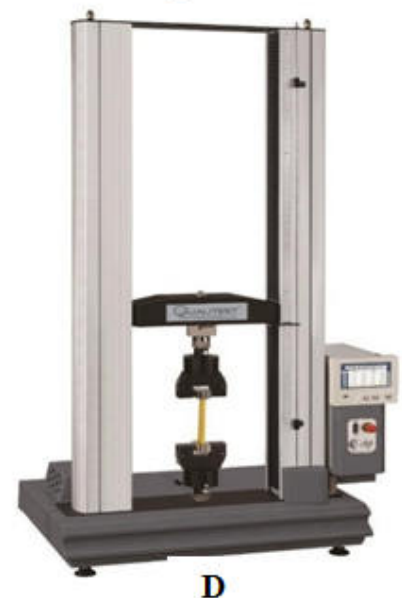

Fig.6. A is apparatus DFX200 High speed Xenon-pulse delivery source and solid state PIN detector for thermal conductivity Measure ,B is apparatus $\mathrm{XQK}$ Ceramic refractory products apparent porosity bulk density ,C is apparatus of PERCISIONto measure the cold crushing strength ,D is apparatus of universal testing machine to test the permanent linear change

The bulk density test was conducted at temperatures $105^{\circ} \mathrm{C}, 815^{\circ} \mathrm{C}$, where each sample from each category were tested, the total tested samples are 24 . The cold crushing test was conducted at temperatures $105^{\circ} \mathrm{C}, 815^{\circ} \mathrm{C}, 1095$ ${ }^{\circ} \mathrm{C}, 1370^{\circ} \mathrm{C}$, the overall samples are 48 .The permanent liner change test was conducted at temperatures $105^{\circ} \mathrm{C}$, $815^{\circ} \mathrm{C}, 1095^{\circ} \mathrm{C}, 1370^{\circ} \mathrm{C}, 1600^{\circ} \mathrm{C}, 1820^{\circ} \mathrm{C}$ the total numbers of these samples are 72 . The thermal conductivity test also was conducted at temperatures $205^{\circ} \mathrm{C}, 425^{\circ} \mathrm{C}, 650^{\circ} \mathrm{C}, 870^{\circ} \mathrm{C}, 1095^{\circ} \mathrm{C}, 1315^{\circ} \mathrm{C}$ with over all samples up to 72 .

\section{Results and Discussion}

\subsection{The Measurement of Bulk Density}

The test samples in accordance to the recipes as illustrated in table 1 was tested by device of XQK Ceramic refractory to measure the bulk densities of test samples, the results showed (Fig.7)\&Table.2. that the values at measuring temperature $105^{\circ} \mathrm{C}$ are $3320,3150,3050 \mathrm{Kg} / \mathrm{m}^{3}$ for the samples; Al01,A102,A103(category A) with alumina percentage ranging from $99.5 \%, 95 \%, 90 \%$ respectively, and showed sever decrease in the value of bulk density up to $2550 \mathrm{Kg} / \mathrm{m}^{3}$ at the sample A104(Category B), where such decreasing appears when added a 
considerable amount of calcium carbonate as source of $\mathrm{CaO}$ with percentage up to $5 \%$, the increasing of $\mathrm{CaO}$ percentage resulting also slight increase in the bulk densities values of A105,A106(category)with values;2700 $\mathrm{Kg} / \mathrm{m}^{3}, 2600 \mathrm{Kg} / \mathrm{m}^{3}$.at the samples A107,A108,A109(Category C)it was noticed that when added 5,6,7 \% respectively of white sand as source of $\mathrm{SiO} 2$ and amount of apatite as source of $\mathrm{P} 2 \mathrm{O} 5 \%$;3.2.5.2,7.2 respectively and fixed amount of $\mathrm{TiO} 2$ as $0.1 \%$ it was noticed that the values of bulk densities are; $2920 \mathrm{Kg} / \mathrm{m}^{3}, 2700 \mathrm{Kg} / \mathrm{m}^{3}, 2600 \mathrm{Kg} / \mathrm{m}^{3}$ respectively but it can considered that such change in the bulk values are considering smooth change form sample A104 to A109 but at sample A110 was noticed that the value was severe decreased to $1750 \mathrm{Kg} / \mathrm{m}^{3}$ and the samples Al11,Al12 continue to decrease to values $1550 \mathrm{Kg} / \mathrm{m}^{3}, 1300 \mathrm{Kg} / \mathrm{m}^{3}$ respectively, such decrease in bulk densities was due to the absence of

$\mathrm{P}_{2} \mathrm{O}_{5}$ and fixed amount of $\mathrm{TiO}_{2} ; 0.1 \%$ and ascending value of $\mathrm{CaO} ; 4.4,8.4,13.4 \%$ respectively and descending value of $\mathrm{Al}_{2} \mathrm{O}_{3} ; 94.5 \%, 90.5 \%, 85.5 \%$.

Regarding to the temperature $815^{\circ} \mathrm{C}$, the results of test samples showed almost agreement of the values of bulk densities at $105^{\circ} \mathrm{C}$, except a severe change of the bulk density value of sample $\mathrm{A} 103$, where the value dropped from $3050 \mathrm{Kg} / \mathrm{m}^{3}$ to $2050 \mathrm{Kg} / \mathrm{m}^{3}$ such severe drop was noticed at the value of $90 \%$ of $\mathrm{Al}_{2} \mathrm{O}_{3}$.

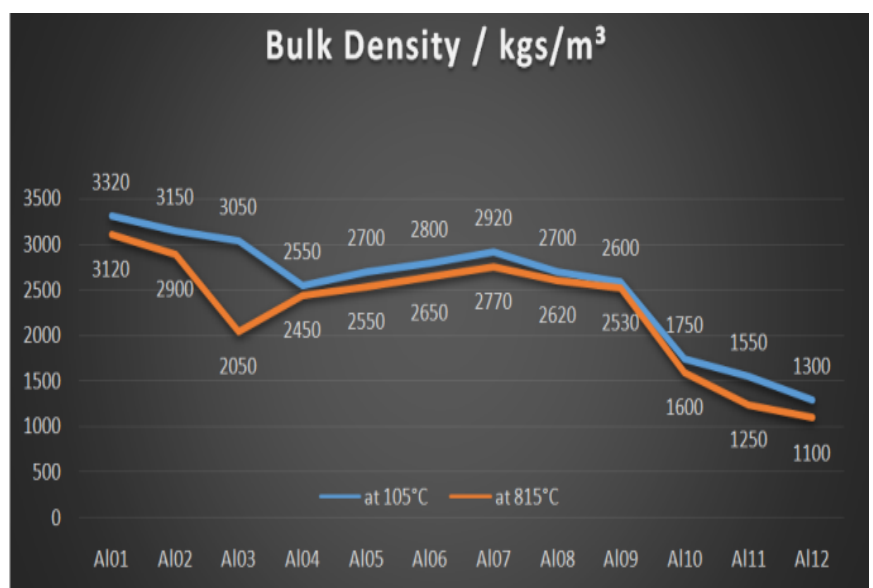

Fig.7: Bulk density of test samples at testing temperature of $105^{\circ} \mathrm{C}, 815^{\circ} \mathrm{C}$

Table.2: The Results of Bulk Densities

\begin{tabular}{|c|c|c|c|}
\hline \multicolumn{2}{|c|}{ CHARACTERISTICS } & \multicolumn{2}{|c|}{ Bulk density / kgs/m³ } \\
\hline \multirow{4}{*}{ Category A } & - & (a) $105^{\circ} \mathrm{C}$ & (a) $815^{\circ} \mathrm{C}$ \\
\hline & $\mathrm{A} 101$ & 3320 & 3120 \\
\hline & $\mathrm{A} 102$ & 3150 & 2900 \\
\hline & A103 & 3050 & 2050 \\
\hline \multirow{3}{*}{ Category B } & $\mathrm{A} 104$ & 2550 & 2450 \\
\hline & A105 & 2700 & 2550 \\
\hline & A106 & 2800 & 2650 \\
\hline \multirow{3}{*}{$\underline{\text { Category } \mathrm{C}}$} & A107 & 2920 & 2770 \\
\hline & A108 & 2700 & 2620 \\
\hline & A109 & 2600 & 2530 \\
\hline \multirow{3}{*}{ Category D } & A110 & 1750 & 1600 \\
\hline & Al11 & 1550 & 1250 \\
\hline & Al12 & 1300 & 1100 \\
\hline
\end{tabular}




\subsection{Measuring of the Cold Crushing Strength.}

The cold crushing strength test was conducted in accordance to ASTM C133 and C856 and used apparatus of PERCISION.the test was conducted at temperatures $105^{\circ} \mathrm{C}, 815^{\circ} \mathrm{C}, 1095^{\circ} \mathrm{C}, 1370^{\circ} \mathrm{C}$ the results of the test $($ table 3\&Fig.8). at $105^{\circ} \mathrm{C}$ was ranging from 80 to $14 \mathrm{MPa}$ with slightly descending for the samples AL01 to Al12 . the samples A104,Al05,A106 showed durable and stable strength at temperatures $815^{\circ} \mathrm{C}, 1370^{\circ} \mathrm{C}$ where they showed strength values almost compatible 47,40-42,37-38 Mpa respectively, where adding calcium carbonate provide the samples such stability at such materials balance. The cold crushing strength was direct proportional with value of alumina percentage.

Table.3: Results of the cold crushing strength

\begin{tabular}{|c|c|c|c|c|c|}
\hline \multicolumn{2}{|c|}{ CHARACTERISTICS } & \multicolumn{4}{c|}{ Cold Crushing Strength - ASTM C133 and C865 - MPa } \\
\hline \multirow{4}{*}{ Category A } & - & $@ 105^{\circ} \mathrm{C}$ & at $815^{\circ} \mathrm{C}$ & $@ 1095^{\circ} \mathrm{C}$ & $@ 1370^{\circ} \mathrm{C}$ \\
\cline { 2 - 6 } & $\mathrm{A} 101$ & 80 & 73 & 66 & 55 \\
\cline { 2 - 6 } & $\mathrm{A} 102$ & 70 & 62 & 54 & 43 \\
\cline { 2 - 6 } & $\mathrm{A} 103$ & 66 & 52 & 40 & 32 \\
\hline \multirow{4}{*}{ Category B } & & $@ 105^{\circ} \mathrm{C}$ & $@ 815^{\circ} \mathrm{C}$ & $@ 1095^{\circ} \mathrm{C}$ & $@ 1370^{\circ} \mathrm{C}$ \\
\cline { 2 - 6 } & $\mathrm{A} 104$ & 58 & 47 & 34 & 47 \\
\cline { 2 - 6 } & $\mathrm{A} 105$ & 55 & 42 & 30 & 40 \\
\cline { 2 - 6 } & $\mathrm{A} 106$ & 40 & 38 & 25 & 37 \\
\hline \multirow{4}{*}{ Category C } & & $@ 105{ }^{\circ} \mathrm{C}$ & $@ 815^{\circ} \mathrm{C}$ & $@ 1095^{\circ} \mathrm{C}$ & $@ 1370^{\circ} \mathrm{C}$ \\
\cline { 2 - 6 } & $\mathrm{A} 107$ & 44 & 33.5 & 22 & 15 \\
\cline { 2 - 6 } & $\mathrm{A} 108$ & 30.15 & 28.5 & 24 & 18 \\
\cline { 2 - 6 } & $\mathrm{A} 109$ & 27 & 20.15 & 18 & 13 \\
\hline \multirow{4}{*}{ Category D } & & $@ 105^{\circ} \mathrm{C}$ & $@ 815^{\circ} \mathrm{C}$ & $@ 1095^{\circ} \mathrm{C}$ & $@ 1370^{\circ} \mathrm{C}$ \\
\cline { 2 - 6 } & $\mathrm{A} 110$ & 20 & 7.5 & 7.5 & 11.5 \\
\cline { 2 - 6 } & $\mathrm{A} 111$ & 18 & 6 & 5.78 & 10 \\
\cline { 2 - 6 } & $\mathrm{A} 112$ & 14 & 5 & 4.55 & 8 \\
\hline
\end{tabular}

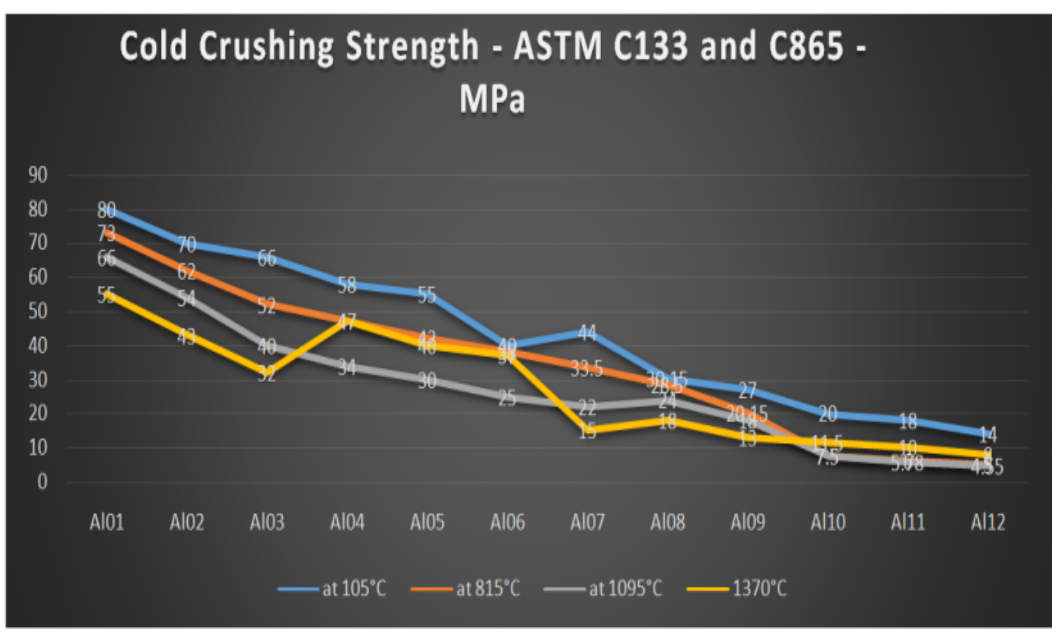

Fig.8.cold crushing strength of test samples at testing temperature of $105^{\circ} \mathrm{C}, 1370^{\circ} \mathrm{C}$

\subsection{Measuring of the Permanent Linear Change}

The test samples were tested by apparatus of universal testing machine at temperatures $105^{\circ} \mathrm{C}, 815^{\circ} \mathrm{C}, 1095^{\circ} \mathrm{C}$, $1370^{\circ} \mathrm{C}, 1600^{\circ} \mathrm{C}, 1820^{\circ} \mathrm{C}$. The results showed (Fig.9.)that the PLC percentage at $105^{\circ} \mathrm{C}$ for sample $\mathrm{Al} 01, \mathrm{Al} 02$, 
Al03 are; $0.1 \%, 0.6 \%, 0.9 \%$ and suddenly decreased to $0 \%$ at sample A104, where the addition of Cao caused this amendment and started again to slightly increased but returned again to value zero \%,at the sample A106 such decrease in the value of PLC was due to increasing the percentage of Cao to 7\%.the with the decreasing of alumina percentage. It is noticed that the values of PLC at temperatures $105^{\circ} \mathrm{C}, 815^{\circ} \mathrm{C}, 1095{ }^{\circ} \mathrm{C}, 1370{ }^{\circ} \mathrm{C}$, $1600^{\circ} \mathrm{C}$ are almost agreed for the samples A101,A102,A103, the values were noticed to be increased at samples A107,A108,A109 at temperatures $815^{\circ} \mathrm{C}, 1095^{\circ} \mathrm{C}, 1370^{\circ} \mathrm{C}, 1600^{\circ} \mathrm{C}$, where at those samples has doped with considerable amount of $\mathrm{SiO} 2 \mathrm{P} 2 \mathrm{O} 5$ as shown in table 1.the results showed also that the sample A1010 showed lowest PLC at highest temperature $1820^{\circ} \mathrm{C}$.

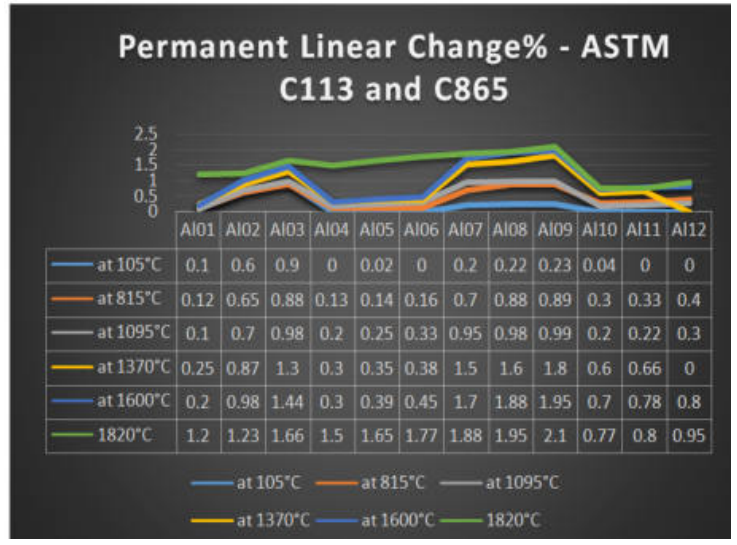

Fig.9: Permanent linear change $\%$ at testing temperature of $105^{\circ} \mathrm{C}, 815^{\circ} \mathrm{C}, 1095^{\circ} \mathrm{C}$, $1370^{\circ} \mathrm{C}, 1600^{\circ} \mathrm{C}, 1820^{\circ} \mathrm{C}$.

\subsection{Measuring of theThermal conductivity}

The thermal conductivity was measured for test samples by apparatus DFX200 High speed Xenon, the results showed (Fig.10) that the category A for samples A101,Alo2,A103 have been almost agreed in the values of its thermal conductivity at temperatures; $205^{\circ} \mathrm{C}, 425^{\circ} \mathrm{C}, 650^{\circ} \mathrm{C}, 870^{\circ} \mathrm{C}, 1095^{\circ} \mathrm{C}, 1315^{\circ} \mathrm{C}$, where the values ranging from $1.89 \mathrm{w} \cdot \mathrm{m}^{-1} \cdot \mathrm{k}^{-1}$ to $1.29 \mathrm{w} \cdot \mathrm{m}^{-1} \cdot \mathrm{k}^{-1}$ for the sample $\mathrm{Al} 101$ at temperature $205^{\circ} \mathrm{C}, \mathrm{A} 103$ at temperature $1095^{\circ} \mathrm{C}$ respectively. Regarding to the samples A104, A105, A106 (category B) showed disagreement in its value at the test temperatures due to doping of Cao and traces of Alkaline, where they showed sudden increase in thermal conductivity; up to $4.41 \mathrm{w} \cdot \mathrm{m}^{-1} \cdot \mathrm{k}^{-1}$ for the sample $\mathrm{A} 103$ at temperature $205^{\circ} \mathrm{C}$. Regarding to the sample $\mathrm{A} 107, \mathrm{~A} 108$, A109 (category C) their thermal conductivity started again to be decreased to values $2.28 \mathrm{w} \cdot \mathrm{m}^{-1} \cdot \mathrm{k}^{-1}, 2.2 \mathrm{w} \cdot \mathrm{m}^{-1} \cdot \mathrm{k}^{-1}$ $.1 .98 \mathrm{w} \cdot \mathrm{m}^{-1} \cdot \mathrm{k}^{-1}$ respectively at temperatures $205 \mathrm{oC}$, and showed almost stability and agreement of its values at escalated temperatures up to $1315^{\circ} \mathrm{C}$ where the lowest thermal conductivity recorded for the sample A109 at temperature of $1315^{\circ} \mathrm{C}$ with value of thermal conductivity $1.95 \mathrm{w} \cdot \mathrm{m}^{-1} \cdot \mathrm{k}^{-1}$. Regarding to the samples A109,A110.A111(category D) showed also almost agreement in its thermal conductivity values, where the lowest thermal conductivity values was recorded for the sample Al10 with value up to $0.8 \mathrm{w} \cdot \mathrm{m}^{-1} \cdot \mathrm{k}^{-1}$ 


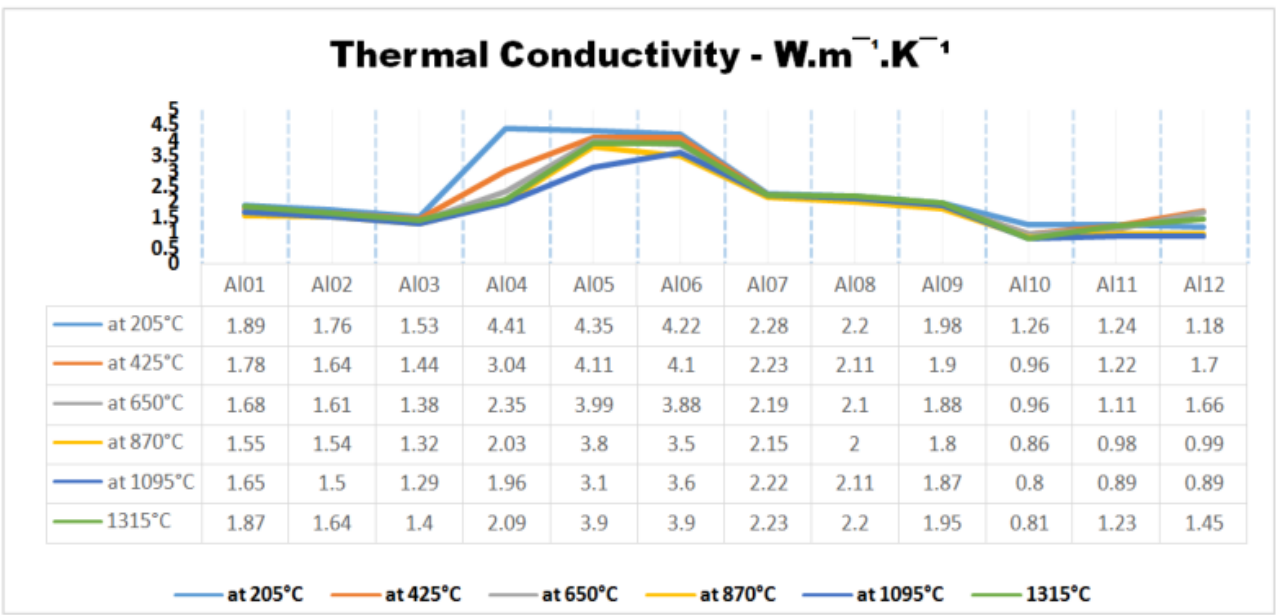

Fig.10. the thermal Conductivity at testing temperature of $205^{\circ} \mathrm{C}, 425^{\circ} \mathrm{C}, 650^{\circ} \mathrm{C}, 870{ }^{\circ} \mathrm{C}, 1095^{\circ} \mathrm{C}, 1315^{\circ} \mathrm{C}$

\section{Conclusions}

- High alumina samples were tested and evaluated to be used as refractory materials for steam reformer reactor, which it is main process for producing hydrogen required for ammonia production ,this articles provide the fabricator the ability to select the material which suitable for his application which required mechanical durability and low thermal conductivity, the data provided in this article make the fabricator has the wide range application to select material with low thermal conductivity and high mechanical properties .there was clear correlation between high bulk density and the high cold crushing strength where the sample Al01 showed the highest bulk density with value $3320 \mathrm{kgs} / \mathrm{m} 3$ and $3120 \mathrm{kgs} / \mathrm{m} 3$ at temperatures $105^{\circ} \mathrm{C}, 815^{\circ} \mathrm{C}$ respectively and maximum cold crushing strength $80 \mathrm{Mpa}$ and $73 \mathrm{Mpa}$ at the same temperatures respectively where escalated alumina content contributed effectively to show high bulk density and high cold crushing strength .

- Regarding to the permanent linear change which it is important for the fabricator to receive materials with minimum linear change at highest temperatures, the sample Al12 (category C)showed minimum linear change at temperature up to $1820^{\circ} \mathrm{C}$ with percentage up to $0.95 \%$, where the balancing between alkalis and Cao with percentage up to $13.4 \%$ contributed effectively to receive such result.

- Regarding to the thermal conductivity also itis indispensable to get refractory materials with lowest value of thermal conductivity and also category $\mathrm{C}$ of sample Al10 showed lowest thermal conductivity at 0.81 w. $\mathrm{m}^{-1} \cdot \mathrm{k}^{-1}$ at highest temperature at $1315^{\circ} \mathrm{C}$.

\section{$\underline{\text { References }}$}

1. Ogden, J.M. (1999). "Prospects for building a hydrogen energy infrastructure". Annual Review of Energy and the Environment. 24: 2279. doi:10.1146/annurev.energy.24.1.227.

2. "Hydrogen Production: Natural Gas Reforming". Department of Energy. Retrieved 6 April 2017.

3. Rostrup-Nielsen. "Large-scale Hydrogen Production" (PDF). Haldor Topsøe. p. 3. The total hydrogen market was in $1998390 \cdot 10^{\wedge} 9 \mathrm{Nm} 3 / \mathrm{y}+110 \cdot 10^{\wedge} 9 \mathrm{Nm} 3 / \mathrm{y}$ co-production.

4. Crabtree, George W.; Dresselhaus, Mildred S.; Buchanan, Michelle V. (2004). The Hydrogen

Economy (PDF) (Technical report). 
5. Kima Project technical office, engineering drawing of Marie Technimont (2017).

6. The Material data recommendation of KBR, No 3698-WB-V-FO01054124013.

7. ASTM C113 and C865.

8. ASTM C133 and 865

9. KBR specifications No D940-PVL-DOME, 2017 issue 04.

10. KBR Specifications NO D940-PVRS-103D, 2017 issue 04.

11. KBR Specifications NO MB11-6M,2017 issue 04.

12. KBR Specifications NO MB11-2TS, 2017 issue 04.

13. KBR Specifications NO P11-4TS.,2017 issue 04

14. KBR Specifications NOD940-302-CPS, 2017 issue 04.

15. Specifications of primary reformer No3698-WB-VD-FO01054124012,2017,issue 01 ASTMC860. 